\title{
XRF 分析におけるファンダメンタルパラメータ法の開発と応用
}

\author{
片岡 由行*1, 河野 久征 ${ }^{1}$, 河原 直樹 ${ }^{1}$, 越智 寛友 ${ }^{2}$, 西 埜 誠 $^{3}$, 中村 秀樹 $^{3}$
}

\begin{abstract}
蛍光 X 線分析におけるファンダメンタルパラメータ法（FP 法）は, 理論的に蛍光 X 線強度を計算して定 量分析に利用する方法である. FP 法を搭載した波長分散型蛍光 X 線分析装置は, 1980 年代後半に国内 X 線 機器メーカーであるリガクと島津製作所が世界に先駆けて開発し，エネルギー分散型装置への適用を含め機 能拡張と改良を重ね, その応用範囲も拡大し一般的に使用されるようになった. FP 法の代表的な応用例とし て標準試料を必要としないスタンダードレス分析があるが, 電子材料やめっき分析に使用される薄膜 FP 法, また，従来の検量線法に打けるマトリックス補正係数に，FP 法を利用して求めた係数を使用する方法も，各 種材料の JIS や ISO の分析規格として採用されている．また，蛍光 X 線に加え，散乱線強度を含めた FP 法 も開発し, ポリマーや生体試料の分析や不定形試料の分析にも応用されており, 著者らが開発した FP 法は, 蛍光 X 線分析の応用範囲の拡大に大きく貢献することができたと考えている.
\end{abstract}

\section{1 緒言}

蛍光 X 線分析において, 試料から発生する蛍光 X 線の物 理的発生原理が詳細に解明されており, X 線管から試料に 入射する一次 X 線の波長分布, 試料中の各元素の吸収減衰 係数など各種物理的基礎定数（ファンダメンタルパラメー 夕）と試料の組成から正確に蛍光 X 線強度を理論計算で求 めることができる.ファンダメンタルパラメータ法（FP 法）とは, 試料から発生するX 線強度を, 試料中の成分と その組成 (含有率), 一次 X 線の波長分布, 各種物理的基 礎定数及び装置定数を用いて理論的に計算し, 分析試料の 定量演算や補正係数計算などに利用する方法である. FP法 の用途は, FP 法を用いた定量分析のほかに, 検量線法に使 用するマトリックス (吸収励起) 補正係数を FP 法で求め る方法もある.

FP 法で使用する蛍光 X 線の理論強度計算式は, 1955 年 にSherman ${ }^{1)} に よ り$ 発表され, 1966 年に白岩ら ${ }^{2}$ による二

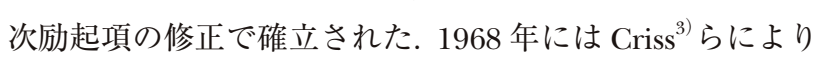
蛍光X線の理論強度計算を用いて測定強度から含有率を求 めるアルゴリズムが発表され，これにより FP 法による定 量分析が確立されたと言ってよい. 日本国内では, 1973 年 に鉄及び鋼一蛍光 X 線分析方法JIS G $1256^{4)}$ が制定された. この JIS 規格では, FP 法で計算した蛍光 X 線の理論強度を

\footnotetext{
* E-mail : kataoka@rigaku.co.jp

${ }^{1}$ 株式会社リガク：569-1146 大阪府高梘市赤大路町 14-8

2 株式会社島津総合サービスリサーチセンター：604-8511 京都 府京都市中京区西ノ京桑原町 1

${ }^{3}$ 株式会社島津製作所分析計測事業部：604-8511 京都府京都市 中京区西ノ京桑原町 1
}

用いて検量線法の理論マトリックス補正係数が計算され使 用されており，実際の工業分析に理論マトリックス補正係 数が使用されたのは，これが世界で最初であった．また， 薄膜試料の分析については, 1977年にLaguitton ${ }^{5}$ らにより 薄膜試料の理論強度計算式を使用した薄膜分析プログラム LAMA が発表されている。 この時点までの FP 法の演算に は大型コンピュータが必要であり, FP 法を使用した定量分 析の一般化には至らなかった。 1977 年には, 分析室で使用 される小型コンピュータで動作する市販 FP 法ソフトウエ ア “XRF-11” が $\mathrm{Criss}^{6}{ }^{6}$ により開発・発売されたが，機能及 び演算速度の関係で普及は限定的であった。

1985 年にリガクの前身である理学電機工業は, バルク, 薄膜 FP 法及びスタンダードレス分析機能を搭載した波長 分散型蛍光 X 線 (WDXRF) 分析装置 System3370 シリーズ を開発した。これは，X線装置メーカーが開発した FP 法 分析システムを搭載した，世界で初の WDXRF 分析装置で あった。また，これに続き，島津製作所は 1980 年代後半 に同様の機能を有するWDXRF 分析装置 VF-320A を販売開 始した ${ }^{7)}$. 両社に所属する著者らは，その後も，散乱線を 用いた FP 法などスタンダードレス分析をはじめとして多 くの機能追加, FP 法の改良, エネルギー分散型蛍光 X 線 （EDXRF）分析装置への適用を継続的に進めており，国 内・海外に扔いて蛍光X線分析の応用分野の拡大に大きく 貢献できたと考えている.

$$
2 \text { FP 法とは }
$$

\section{$2 \cdot 1$ 検量線法と FP 法の比較}

従来から使用されている検量線法では, Fig. 1 (a) に示 


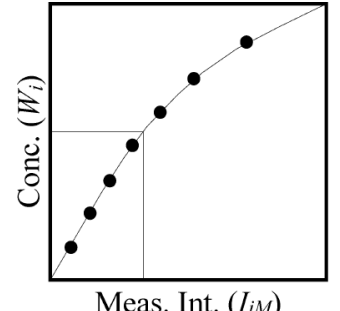

Meas. Int. ( $\left.I_{i M}\right)$

(a) Calibration method

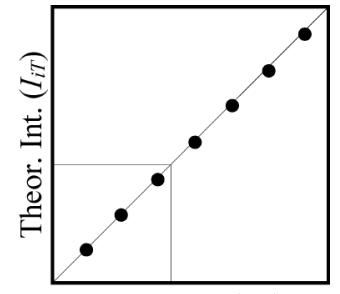

Meas. Int. $\left(I_{i M}\right)$

(b) FP method
Fig. 1 Calibration and FP methods

すように, 分析成分の含有率 $W_{i}$ と測定強度 $I_{i}$ の相関を示 す検量線を使用し, 通常, 次の検量線式を使用する.

$$
W_{i}=\left(a I_{i}^{2}+b I_{i}+c\right)\left(1+\Sigma d_{j} W_{j}\right)
$$

$a, b, c$ は検量線定数, $W_{j}$ は共存元素の含有率で, $d_{j}$ は共 存元素のマトリックス補正係数である. 含有率範囲が広い 場合は, 検量線が曲線となるため, 多くの標準試料を必要 とする. また，共存元素のマトリックス補正係数を実験的 に求める場合には, さらに多くの標準試料を必要とする難 点があった。

一方, FP 法で定量分析を行う場合には, 検量線の代わり に Fig. 1 (b) の理論強度 $I_{i T}$ と測定強度 $I_{i M}$ の相関である感 度曲線を使用し，次式を使用する。

$$
I_{i T}=a I_{i M}{ }^{2}+b I_{i M}+c
$$

式(2) は二次式としているが, ほとんどの場合は, 含有 率範囲によらず $a=0$, すなわち直線となる。このとき, 少 数 (最低 1 点) の標準試料で感度曲線の作成が行える.こ の特徴を利用したのがスタンダードレス分析である。ま た，検量線法では分析できない多層を含む薄膜試料分析 や, FP 法による理論強度を利用して計算で求めた理論マト リックス補正係数の検量線法への適用も可能となるなどの 利点がある.

\section{2・2 FP 法の定量演算方法}

検量線法では，式(1) を使用して，まず検量線定数と測 定強度から各成分の未補正定量值を求め, これらを初期值 として, 各元素の定量值をマトリックス補正項の含有率 $W_{j}$ に代入し, 補正定量值を計算する。これを全元素の定量値 が収束するまで繰り返す。この繰返し計算による定量值計 算の考え方は，FP 法にも使われている.

Fig. 2 に, FP 法におけるバルク試料の定量分析の演算手 順を示す。最初に, 測定強度を理論強度スケールに換算し (ステップ (1)), 次に, 各元素の換算測定強度と純物質と の強度比から含有率を推定しこの含有率を 100 mass\%に

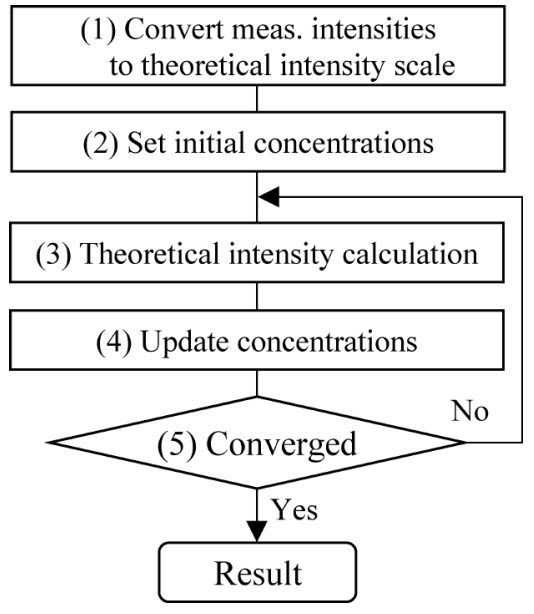

Fig. 2 Quantification scheme in FP method

規格化して初期含有率とする（ステップ（2））、ステップ （3）では，現在の組成における各分析線の理論強度を計算 し，ステップ (4) で換算測定強度と理論強度の強度比を基 に含有率を更新したうえで全元素の含有率を 100 mass\% に規格化する．全元素の含有率が収束するまでステップ （3），(4）を繰り返す. 収束判定は, 各繰返しで各元素の含 有率の相対変化率が一定值以下（たとえば $0.001 ） の$ 判定 条件で行う. 通常, 数回程度の繰返しで収束值が得られる.

多層膜を含む薄膜試料においても，上記と同じ手順で計 算する. ステップ（2）の各層の厚さと組成の初期值設定 は, あらかじめ手入力した值を使用する場合が多い. また, ステップ (4) では, まず, 膜厚及び各成分の含有率が微小 量変化したときの理論強度の変化率を求める，次に，換算 測定強度と理論強度の差と, 膜厚と各成分の含有率の変化 に対する理論強度の変化率から, 連立方程式を解いて, 膜 厚と各成分の含有率を推定する。

\section{$2 \cdot 3$ 蛍光 $X$ 線の理論強度計算}

蛍光 $\mathrm{X}$ 線強度の理論計算は, 蛍光 $\mathrm{X}$ 線の各発生過程の物 理現象を反映させた理論強度計算式を使用する。バルク試 料における理論強度計算式は, 前述の白岩ら ${ }^{2)}$ の論文に詳 しく解説されている，蛍光 $\mathrm{X}$ 線強度の理論計算は, 通常, 入射 X 線で励起された一次励起と, 一次励起で発生した他 の蛍光X線が対象となる蛍光X線を励起する二次励起とを 対象とする (Fig. 3).

バルクの理論強度式を下記に示す. $I_{p i}$ は一次励起, $I_{s i}$ は 二次励起の蛍光 $\mathrm{X}$ 線強度で, 合計強度を理論強度として使 用する。

$$
I_{i}=I_{p i}+I_{s i}
$$




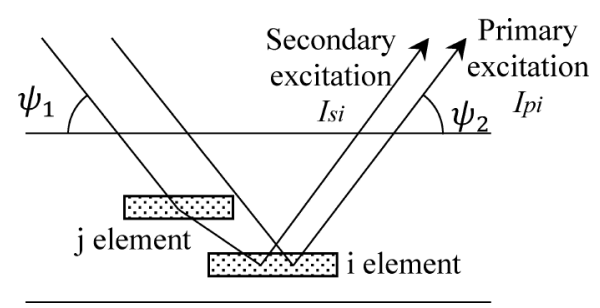

Fig. 3 Primary and secondary excitations

$$
\begin{aligned}
I_{p i} & =\frac{K\left(\lambda_{i}\right)}{\sin \psi_{2}} \int_{\lambda_{\min }}^{\lambda_{e}^{i}} \frac{Q_{i}(\lambda)}{X} I_{0}(\lambda) d \lambda \\
I_{s i} & =\frac{K\left(\lambda_{i}\right)}{2 \sin \psi_{2}} \sum_{j} \int_{\lambda_{\min }}^{\lambda_{e}^{i}} \frac{Q_{j}(\lambda) Q_{i}\left(\lambda_{j}\right)}{X} I_{0}(\lambda) Y d \lambda
\end{aligned}
$$

但し,

$$
\begin{aligned}
& Q_{i}(\lambda)=\tau_{i}(\lambda) W_{i}\left(1-\frac{1}{J_{i}}\right) \omega_{i} R_{p}^{i} \\
& X=\frac{\mu(\lambda)}{\sin \psi_{1}}+\frac{\mu\left(\lambda_{i}\right)}{\sin \psi_{2}} \\
& Y=\frac{\sin \psi_{1}}{\mu(\lambda)} \ln \left(1+\frac{\mu(\lambda)}{\mu\left(\lambda_{j}\right) \sin \psi_{1}}\right) \\
& +\frac{\sin \psi_{2}}{\mu\left(\lambda_{i}\right)} \ln \left(1+\frac{\mu\left(\lambda_{i}\right)}{\mu\left(\lambda_{j}\right) \sin \psi_{2}}\right) \\
& \mu(\lambda)=\sum \mu_{i}(\lambda) W_{i}
\end{aligned}
$$

上式において, $W_{i}$ は試料中の $\mathrm{i}$ 元素の質量分率である. 基礎定数としては, $\mu(\lambda)$ は, 波長 $\lambda$ に対する試料の質量減 衰係数で, 各元素の質量減衰係数 $\mu_{i}(\lambda)$ と質量分率の積の 総和で求める. $\omega_{i}, J_{i}, R_{p}^{i}$ は, 蛍光 X 線の発生に関係し, そ れぞれ, i 元素の蛍光収率, 吸収端ジャンプ比, 遷移確率で ある. $\lambda_{i}, \lambda_{e}^{i}$ は, 対象とする蛍光 $\mathrm{X}$ 線の波長と, その蛍光 $\mathrm{X}$ 線を発生する入射 $\mathrm{X}$ 線の最低エネルギーに対応する吸収端 波長である。また，装置に依存するパラメータとして， $I_{0}(\lambda)$ は一次 $\mathrm{X}$ 線分布で波長 $\lambda$ の強度に相当し, 蛍光 $\mathrm{X}$ 線 強度の計算では波長積分を行う。 $\psi_{1}$ は一次 X 線と試料面間 の入射角度, $\psi_{2}$ は試料面と検出方向間の取出角度である. $K\left(\lambda_{i}\right)$ は装置ファクターである.

上記は, 試料の厚さが X 線的に無限厚としたバルク試料 モデルの式であるが, 多層を含む薄膜の場合は, 各層につ いて深さ方向の積分を行い, 層間の吸収と励起を計算に含 める.

一次 X 線分布 $I_{0}(\lambda)$ は, 実際に使用する X 線管の種類, ターゲット材質と管電圧に合ったデータを使用し, 質量減 衰係数 $\mu$ などの基礎定数は文献值を使用する。これらのパ ラメータの数值は, 文献により異なるので, 最新あるいは

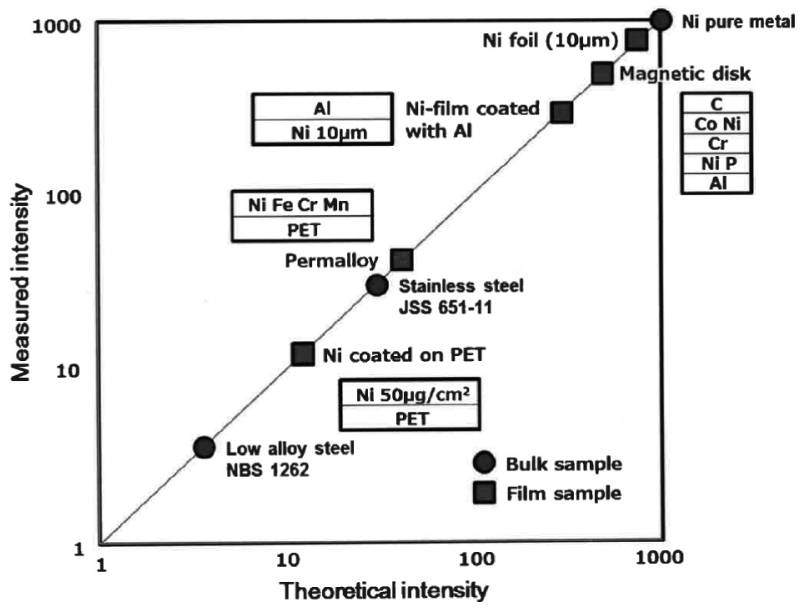

Fig. 4 Relationship between theoretical and measured intensities for $\mathrm{Ni} \mathrm{K} \alpha$

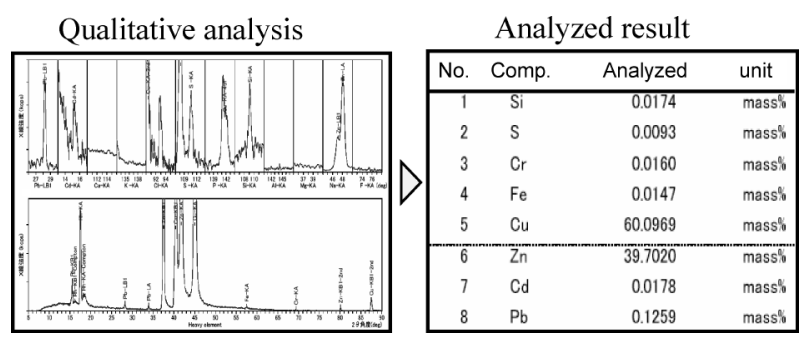

Fig. 5 Standardless analysis

実験による検証で最も信頼性のあるパラメータを使用する ことが重要である.

Fig. 4 に, 組成及び膜厚が既知のバルクの金属や単層, 多層薄膜の各種試料について $\mathrm{Ni} \mathrm{K} \alpha$ 線を測定して得られた 測定 $\mathrm{X}$ 線強度と $\mathrm{Ni} \mathrm{K} \alpha$ 線の理論強度の相関図を示す ${ }^{8)}$. 理 論強度, 測定強度ともに純 $\mathrm{Ni}$ メタルの強度を 1000 として 規格化している。

バルク，薄膜試料にかかわらず非常に直線性のよい比例 相関が得られていることがわかる.このことは，適切に定 量演算を行えば, 純物質の標準試料で作成した感度曲線を 使用して，バルク，薄膜のいずれの場合でも定量分析が可 能であることを示している.

\section{FP 法の応用}

蛍光 X 線分析における FP 法には種々の応用がある。こ こでは，標準試料を必要としないスタンダードレス分析， 薄膜 FP 法定量分析, 理論マトリックス補正係数を使用し た検量線法，バルク FP 法定量分析及び散乱線の理論強度 計算を用いた FP 法定量分析について紹介する.

\section{$3 \cdot 1 \quad$ スタンダードレス分析 ${ }^{9{ }^{910)}}$}

スタンダードレス分析は, Fig. 5 に示すように定性分析 結果で検出された元素について, そのX 線強度から, あら 
Table 1 Standardless analysis result of polymer (Sample: BCR-680) (Unit: mass \%)

\begin{tabular}{lcccccccccccc}
\hline Element & $\mathrm{Si}$ & $\mathrm{Cl}$ & $\mathrm{Ca}$ & $\mathrm{Ti}$ & $\mathrm{Cr}$ & $\mathrm{As}$ & $\mathrm{Br}$ & $\mathrm{Sr}$ & $\mathrm{Cd}$ & $\mathrm{Ba}$ & $\mathrm{Hg}$ & $\mathrm{Pb}$ \\
\hline Result & 0.0051 & 0.095 & 0.005 & 0.13 & 0.0116 & 0.0032 & 0.078 & 0.004 & 0.0132 & 0.246 & 0.0020 & 0.0101 \\
Std value & - & 0.081 & - & - & 0.0115 & 0.0031 & 0.0808 & - & 0.0140 & - & 0.0025 & 0.0108 \\
\hline
\end{tabular}

Table 2 Standardless analysis result of tomato leaves (Sample: NIST 1573a) (Unit: mass \%)

\begin{tabular}{lcccccccccccc}
\hline Element & $\mathrm{Mg}$ & $\mathrm{Al}$ & $\mathrm{P}$ & $\mathrm{S}$ & $\mathrm{Cl}$ & $\mathrm{K}$ & $\mathrm{Mn}$ & $\mathrm{Fe}$ & $\mathrm{Ni}$ & $\mathrm{Cu}$ & $\mathrm{Zn}$ & $\mathrm{Br}$ \\
\hline Result & 1.10 & 0.0547 & 0.213 & 1.01 & 0.67 & 2.78 & 0.0263 & 0.0374 & 0.0006 & 0.0006 & 0.0028 & 0.13 \\
Std value & 1.20 & 0.0598 & 0.216 & 0.96 & 0.66 & 2.70 & 0.0246 & 0.0368 & 0.0002 & 0.0005 & 0.0031 & 0.13 \\
\hline
\end{tabular}

Table 3 Analyzed result of magneto-optical disc

\begin{tabular}{clccccc}
\hline \multirow{2}{*}{ Layer } & \multirow{2}{*}{ Comp. } & \multirow{2}{*}{ Chem. } & \multicolumn{2}{c}{ Sensitivity library } & \multicolumn{2}{c}{ With standard } \\
\cline { 5 - 7 } & & & X-ray & Error & X-ray & Error \\
\hline \multirow{2}{*}{1} & $\mathrm{Si}_{3} \mathrm{~N}_{4}(\AA)$ & $700-$ & - & - & 718 & 18 \\
2 & Layer $(\AA)$ & 750 & 767 & 17 & 753 & 3 \\
& $\mathrm{~Tb}(\mathrm{~mol} \%)$ & 18.11 & 17.45 & -0.66 & 18.08 & -0.03 \\
& $\mathrm{Co}(\mathrm{mol} \%)$ & 8.25 & 7.68 & -0.57 & 8.17 & -0.08 \\
& $\mathrm{Fe}(\mathrm{mol} \%)$ & 72.64 & 74.87 & 1.23 & 73.75 & 0.11 \\
3 & $\mathrm{Si}_{3} \mathrm{~N}_{4}(\AA)$ & 750 & - & - & 733 & -17 \\
Sub. & $\mathrm{PC}(\mathrm{mm})$ & 1.2 & - & - & - & - \\
\hline
\end{tabular}

かじめ格納されている感度ライブラリと呼ばれる装置感度 を使用して, FP 法を用いて各元素の定量值を求める方法で ある. 分析試料に対応した標準試料を必要とせず, 金属, 酸化物粉末, ポリマーやオイルなど, 組成不明な各種試料 の分析が行える特徵があり, RoHS ほかのスクリーニング 分析などを含め多く利用されている. ただ, 試料情報とし て, 金属か酸化物の種別, あるいは, ポリマーやオイルな どの非測定残分の組成の設定は必要である. 感度ライブラ リには，代表的な元素について純物質などの標準物質を測 定して感度係数を求めて登録されており, それ以外の元素 の感度係数については, 登録されている前後の元素の感度 係数から推定するので, 蛍光 X 線分析で測定可能な全元素 の定量分析が可能になっている.

污泥, スケール, 廃油, 生体試料など非測定残分の組成 が不明な試料については, X 線管ターゲット元素の特性 X 線のコンプトン散乱線とレーリー散乱線の測定強度と FP 法で計算した理論強度を対比して, 非測定残分の組成を平 均原子番号として推定する方法がある ${ }^{11)}$. この方法による ポリマーとトマトの葉の分析結果をそれぞれ Table 1 と Table 2 に示す.

\section{$3 \cdot 2$ 薄膜 FP 法定量分析}

蛍光 X 線分析では, 膜厚の測定感度が非常に優れてお り, 元素により異なるが, 通常, $0.02 \mathrm{~nm} \sim 20 \mu \mathrm{m}$ の膜厚
測定が可能である. Cr めつきなど単元素薄膜は, 検量線法 での膜厚測定が可能であり, ITO 膜などの多成分系薄膜や 多層膜の膜厚・組成分析は, 検量線法では行えないが, 薄 膜 FP 法では分析が可能である.この薄膜 FP 法は, 半導体 ウェーハ上のコーティング膜など各種電子材料や合金めっ きの膜厚に応用されている。

薄膜 FP 法には, 他の薄膜分析手法と比べて, 次の特徵 がある.すなわち，（1）迅速・非破壊分析（2）膜厚・組成 同時分析 (3) 多層膜分析 (4) バルク純物質を標準試料と した分析，が可能であることである。

薄膜 FP 法における感度曲線の作成には，品質管理分析 などでは分析試料と同一品種の標準試料が用いられること もあるが, Fig. 1 が示すように, バルク純物質の標準試料 1 点のみによるものでも, 十分に精確な分析結果が得られ る場合が多い。なお, 多層膜を含め, 薄膜 FP 法の定量分 析には，通常，あらかじめ各層の構成元素を設定する.

分析例として, ポリカーボネート基板上に 3 層構造をも つ光磁気ディスクの分析結果を Table $3^{12)}$ に示す. ここで は, バルク純物質の感度係数を感度ライブラリとして使用 したものと, 光磁気ディスクを標準試料として作成した感 度曲線を使用した場合とを比較している．感度ライブラリ を使用した場合では, 1 層目と 3 層目の $\mathrm{Si}_{3} \mathrm{~N}_{4}$ の厚さは固定 として, $\mathrm{Tb} \mathrm{L} \alpha, \mathrm{Fe} \mathrm{K} \alpha$ と Co K $\alpha$ 線を測定して 2 層目の FeTbCo 層の膜厚と組成分析のみを行っている. また, 光 
Table 4 Analyzed result of double layer coating sheet steel

\begin{tabular}{clccc}
\hline Layer & & Line & Analyzed & Std value \\
\hline \multirow{2}{*}{1} & Mass thick. g m ${ }^{-2}$ & $\mathrm{Cr} \mathrm{K} \alpha$ & 0.344 & 0.359 \\
& Cr mass \% & - & - & 100 \\
2 & Mass thick. g m ${ }^{-2}$ & $\mathrm{Zn} \mathrm{K} \alpha$ & 19.0 & 18.7 \\
& Ni mass \% & Ni K $\alpha$ & 12.2 & 12.4 \\
& Zn mass \% & - & - & Balance \\
Sub. & Fe mass \% & - & - & 100 \\
\hline
\end{tabular}

磁気ディスクの標準試料を使用した場合は, Si K $\alpha$ と N K $\alpha$ 線の測定を追加して, 1 層目と 3 層目の $\mathrm{Si}_{3} \mathrm{~N}_{4}$ の膜厚分析も 行った.

また, めっき分析への応用例として, 鋼板上の $\mathrm{Cr}$ と NiZn の 2 層構造の試料の分析例を Table $4^{13)}$ に示す.この 分析には，標準試料としてステンレス鋼と銅合金を使用し た。

\section{$3 \cdot 3$ 理論マトリックス補正係数を使用した検量線法}

この方法は, SFP 法（セミファンダメンタルパラメータ 法）とも呼ばれ, 鉄鋼, 非鉄, 窯業, 鉱業など多くの産業 分野で使用されている. 国内では, 鉄及び鋼（JIS G $1256^{4)}$ )，耐火物製品（JIS R 2116），セメント（JIS R 5204） などの蛍光 $\mathrm{X}$ 線分析法の規格分析法として採用されてい る.

検量線式は，JIS G 1256 で使用されている“dj 法”（JIS モデルとも呼ぶ）と, 国内・海外で使用されている “ $\alpha$ 法” とがあり，下式のように加補正元素が異なる.

$$
\begin{aligned}
& \mathrm{dj} \text { 法 }-\mathrm{W}_{\mathrm{i}}=\left(\mathrm{aI}_{\mathrm{i}}^{2}+\mathrm{bI}_{\mathrm{i}}+\mathrm{c}\right)\left(1+\sum_{j \neq i, b} d_{j} W_{j}\right) \\
& \alpha \text { 法 }-\mathrm{W}_{\mathrm{i}}=\left(\mathrm{bI}_{\mathrm{i}}+\mathrm{c}\right)\left(1+\sum_{j \neq b} \alpha_{j} W_{j}\right)
\end{aligned}
$$

dj 法は, 加補正元素は分析元素 $\mathrm{i}$ とベース元素 b 以外が 対象となり, 分析元素とベース元素の二元系検量線が基準 検量線となる。この基準検量線は, 含有率範囲が広いとき には曲線となるため二次式が使われている， $\alpha$ 法には，加 補正元素をベース元素以外とする場合と, 分析元素以外と する場合とがあり，それぞれ発表者の名前から, de Jongh モデルと Lachance-Traill モデルと呼ばれている. いずれの $\alpha$ 法も, 基準検量線は近似的に直線となる. いずれのモデ ルでも良好な補正が可能であるが, 非測定成分の有無, 含 有率範囲, 標準試料の数により使用する補正モデルを選択 するとよい.

理論マトリックス補正係数は, 分析対象品種の代表的な 組成から共存成分の含有率を微小量変化させたときの分析 線の理論強度の変化率を, FP法により計算することで算出 される. 理論マトリックス補正係数を使用する利点には,
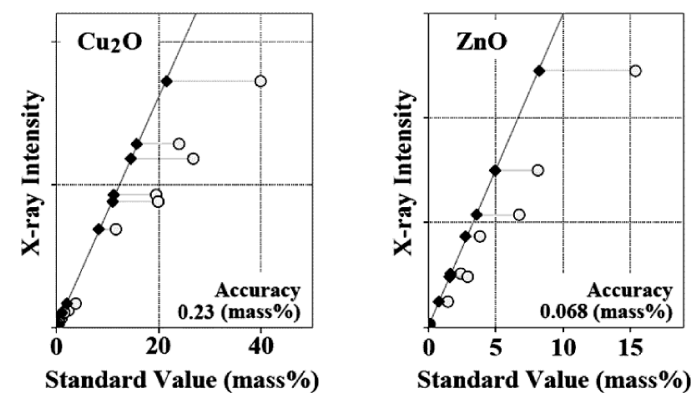

Fig. 6 Calibration curves for copper ores and copper concentrates (open circles: without correction, diamonds: with correction)

（1）マトリックス補正係数を求めるときに標準試料の準備 が不要であること，（2）狭い組成範囲では FP 法と同等の 補正効果があり合金やガラスビード法による酸化物粉末の 分析など均質な試料では正確な分析が可能となること，が あげられる。また, 理論マトリックス補正の機能を拡張す ることで, ガラスビード法による分析において, 強熱減 量・強熱増量や融剤と試料の混合比の補正も可能となって いる. Fig. 6 に, WDXRF 分析装置を用いた, ガラスビード 法による銅鉱石及び銅精鉱中の $\mathrm{Cu}$ と $\mathrm{Zn}$ の理論マトリック ス補正による検量線 ${ }^{14)}$ を示す。銅鉱石と銅精鉱の $\mathrm{Cu}$ と $\mathrm{Zn}$ は, 硫化物として存在しているが, 溶融により酸化される ためガラスビード中では各元素は酸化物となり, 強熱増量 が発生する. Fig. 6 が示すように理論マトリックス補正に より良好な検量線正確度が得られる。ここで, 正確度は, 標準值と定量値の誤差の標準偏差で求めている.

続いて, 理論マトリックス補正の他の応用例として, 粉 末プレス法による鉄鉱石の全鉄の分析例を紹介する。鉄鉱 石の全鉄の分析は特に精確さが要求されるが, 鉱石により ヘマタイトやマグネタイトなど異なる鉄化合物で構成され ている，鉱石により多量の化合水を含んでいる，分析線 $\mathrm{Fe}$ $\mathrm{K} \alpha$ に対して $\mathrm{Ca}$ や $\mathrm{Ti}$ の吸収効果の影響が大きい, といっ た課題がある。これらの課題を解決するため, WDXRF 分 析装置を用い, コンプトン散乱線内標準の検量線に共存補 正項を追加した式(8), 共存補正係数を FP 法で理論マト リックス補正係数を求めて検量線を作成した.

$$
\begin{aligned}
& \mathrm{W}_{\mathrm{Fe}}=\left(\mathrm{aI}_{\mathrm{FeR}}{ }^{2}+\mathrm{bI}_{\mathrm{FeR}}+\mathrm{c}\right)\left(1+\sum_{j \neq i, b} d_{j} W_{j}\right) \\
& \text { 但し, } \mathrm{I}_{\mathrm{FeR}}=\mathrm{I}_{\mathrm{FeK} \alpha} / \mathrm{I}_{\mathrm{RhK} \alpha \text { Compton }}
\end{aligned}
$$

コンプトン散乱線には，Rh ターゲットX 線管からの Rh K $\alpha$ Compton を用いた. Fig. 7 に，(a）散乱線内標準のみ の検量線と（b）散乱線内標準の検量線に式（8）のマトリッ クス補正項を加え FP 法で求めた補正係数を使用して補正 した場合の検量線 ${ }^{15)}$ とを示す.

図が示すように，コンプトン散乱線内標準のみでは補正 

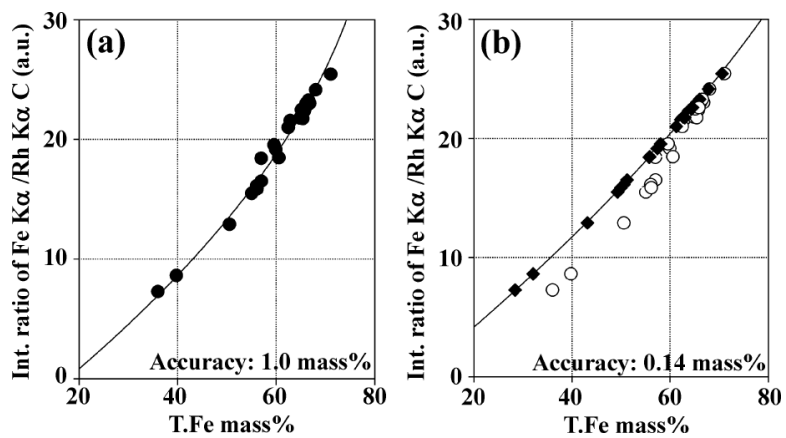

Fig. 7 Calibration curves for total iron in iron ores (a) Calibration only with scattering X-ray internal standard correction. (b) Calibration with both scattering X-ray internal standard and inter-element corrections (open circles: without inter-element correction (same as (a)), diamonds: with interelement correction).
Table 6 Concentration ranges and accuracies of NiFeCo alloys (Unit: mass \%)

\begin{tabular}{clc}
\hline Element & Conc. range & Accuracy \\
\hline $\mathrm{Mn}$ & $0-15.09$ & 0.031 \\
$\mathrm{Si}$ & $0-4.06$ & 0.051 \\
$\mathbf{C r}$ & $\underline{0-39.48}$ & $\mathbf{0 . 1 0}$ \\
$\mathbf{N i}$ & $\underline{0-100 .}$ & $\mathbf{0 . 1 4}$ \\
$\mathbf{C o}$ & $\underline{0-100 .}$ & $\mathbf{0 . 0 7 1}$ \\
$\mathrm{Mo}$ & $0-27.9$ & 0.038 \\
$\mathrm{~W}$ & $0-17.98$ & 0.065 \\
$\mathrm{Nb}$ & $0-5.38$ & 0.009 \\
$\mathrm{Ti}$ & $0-3.19$ & 0.013 \\
$\mathrm{Al}$ & $0-1.74$ & 0.032 \\
$\mathbf{F e}$ & $\underline{0-100 .}$ & $\mathbf{0 . 1 8 )}$ \\
$\mathrm{P}$ & $0-0.32$ & 0.002 \\
$\mathrm{~S}$ & $0-0.03$ & 0.002 \\
$\mathrm{Cu}$ & $0-32.93$ & 0.020 \\
$\mathrm{Ta}$ & $0-0.75$ & 0.008 \\
$\mathrm{~V}$ & $0-2.04$ & 0.012 \\
$\mathrm{Sn}$ & $0-0.09$ & 0.002 \\
\hline
\end{tabular}

Table 5 Analyzed results of nickel, cobalt and titanium alloys using FP method (Unit: mass \%)

\begin{tabular}{llcccccccccc}
\hline \multicolumn{1}{c}{ Sample } & Method & $\mathrm{Mn}$ & $\mathrm{Ni}$ & $\mathrm{Cr}$ & $\mathrm{Mo}$ & $\mathrm{W}$ & $\mathrm{Co}$ & $\mathrm{Ti}$ & $\mathrm{Al}$ & $\mathrm{Fe}$ & $\mathrm{Sn}$ \\
\hline NBS1244 & Std value & 0.29 & 73.2 & 15.7 & 0.20 & - & 0.06 & 0.25 & 0.26 & 9.6 & - \\
Ni alloy & FP method & 0.35 & 72.9 & 15.4 & 0.21 & 0.00 & 0.11 & 0.28 & 0.24 & 10.5 & 0.01 \\
MBHX401B & Std value & 0.27 & 11.5 & 25.0 & - & 7.04 & - & - & - & 0.75 & - \\
Co alloy & FP method & 0.32 & 12.0 & 24.6 & 0.01 & 6.72 & 55.4 & 0.01 & 0.13 & 0.81 & 0.00 \\
No.12 & Std value & - & - & - & 0.95 & - & - & - & 8.00 & 0.10 & - \\
Ti alloy & FP method & 0.00 & 0.01 & 0.08 & 1.08 & 0.00 & 0.00 & 91.1 & 7.55 & 0.13 & 0.02 \\
\hline
\end{tabular}

は不十分で，共存元素補正を加えることにより，0.14 mass \% と良好な検量線正確度が得られた。 なお, 理論マト リックス補正計算においては, JIS モデルを使用し, ベース 元素は酸素とした. Fe K $\alpha$ 線の X 線強度で検量線を作成す る代わりにコンプトン散乱線内標準を使用することによ り, 共存元素の影響度は 10 分の 1 程度に減少するので, $\mathrm{MgO}$ など軽元素成分の分析誤差や化合水の影響を最小限 に留めることができるのがこの方法の利点である.

さらに，散乱線内標準に理論マトリックス補正を加えた 他の応用例として, 潤滑油, 廃油, バイオ燃料などの才イ ルの分析もある. 異なる基油が同一検量線で分析ができ る.この方法では, 内標準の散乱線には, $0.1 〜 0.2 \mathrm{~nm}$ の 波長範囲の連続 X 線の散乱線を使用した ${ }^{16)}$. オイル中の無 機元素である $\mathrm{S}$ や Ca 等の分析に有効であり, 基油の酸素 濃度や $\mathrm{C} / \mathrm{H}$ 比の補正が行える。

\section{$3 \cdot 4$ バルク FP 法定量分析}

バルク FP 法定量分析は, 検量線法と同様に標準試料を 使用して元素ごとの感度曲線を作成し, FP法で定量演算を 行う方法である. 理論マトリックス補正係数を使用する検 量線法と比較して対応できる含有率範囲が非常に広い点が
特徵である. また, 少ない標準試料数でも広い含有率範囲 の分析が行える．この応用例としてWDXRF 分析装置を用 いてニッケル合金, コバルト合金とチタン合金の試料を,

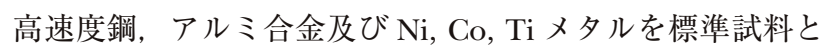
して, 各元素の標準試料が 1 または 2 点で感度曲線を作成 して FP 法で 10 元素の定量分析を行った. 分析結果を Table $5^{7)}$ に示す. 少ない標準試料数にもかかわらず, 良好 な定量分析結果が得られた。

バルク FP 法定量分析においても, 分析試料の組成に近 い標準試料を使用したほうが，より正確な分析が行える. そこで, WDXRF 分析装置を用いて NiFeCo 合金の 17 元素 を標準試料 118 点で感度曲線を作成し, 標準試料を未知試 料として定量分析を行った ${ }^{17)}$. 試料した標準試料の含有率 範囲と各元素の正確度を Table 6 に示す. Ni, Co, Fe は, 含 有率範囲が 0 ～ 100 mass\% であり, Mn, Cr, Mo, Cuも含有 率 0 から高含有率までと含有率範囲は広い. $\mathrm{Ta}, \mathrm{W}$ は $\mathrm{L} \alpha$ 線, それ以外の元素は, $\mathrm{K} \alpha$ 線を分析線とした.

Fig. 8 に Ni K $\alpha$ 線について, Ni K $\alpha$ 線の理論強度と測定 強度の相関である感度曲線を示した. Fig. 8 の Ni K $\alpha$ 線の 感度曲線の相対誤差の標準偏差は $0.13 \%$ であった。

Table 6 の正確度は, 標準試料 118 点の標準試料の定量 


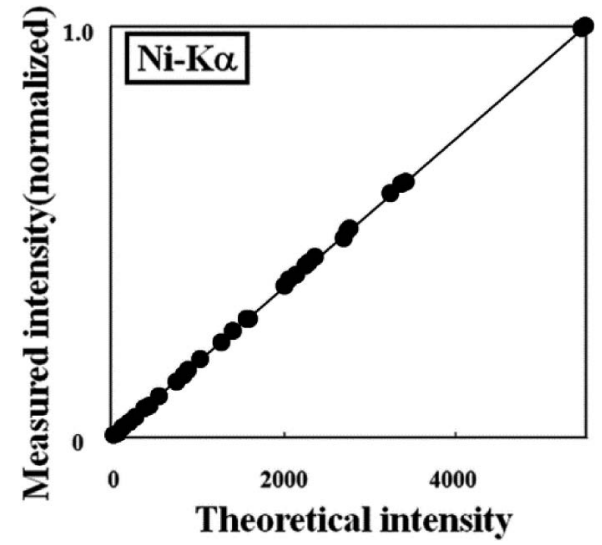

Fig. 8 Sensitivity calibration for Ni K $\alpha$ for Ni Fe Co alloys (Intensities are normalized with pure nickel)

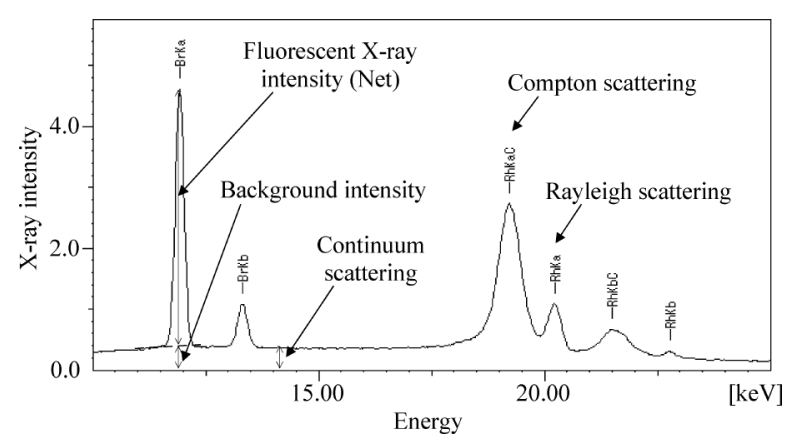

Fig. 9 X-ray spectrum of high energy range (sample: resin)

值から求めた各元素の正確度である. $\mathrm{Cr}, \mathrm{Ni}, \mathrm{Co}$ は, 広い 濃度範囲にもかかわらず 0.1 mass \% 程度の精確さが得ら れた. Fe については, ステンレス鋼などの Feベースの試 料では, $\mathrm{Fe}$ の化学分析值がないため Fe 以外の元素の合計 含有率と 100 mass\% との差を標準值として正確度を求め た。

結果が示すようにFP法定量分析により NiCoFe 合金の微 量から高濃度まで正確な分析が可能であることが確認でき た. 検量線法では, このような組成範囲では多くの品種に 分けてさらに多くの標準試料を用意して検量線を作成する 必要があるが, FP 法では, 各元素につき一つの感度曲線で 分析が可能である.

\section{$3 \cdot 5$ 散乱線の理論強度計算を用いた FP 法定量分析}

$\mathrm{FP}$ 法では, 蛍光 $\mathrm{X}$ 線のほかに, 入射 $\mathrm{X}$ 線が試料中で散 乱した散乱 X 線も定量分析に利用することができる. Fig. 9 に, EDXRF 分析装置で測定した樹脂試料の高エネル ギー領域のスペクトルを示す．FP 法に使用できる散乱線 は, X 線管ターゲット元素の特性 X 線のコンプトン散乱線 とレーリー散乱線及び連続 X 線の散乱線（コンプトン散乱
Table 7 Thickness measurement of polymer films (Unit: $\mu \mathrm{m}$ )

\begin{tabular}{lccc}
\hline \multicolumn{1}{c}{ Sample } & $\begin{array}{c}\text { Measured } \\
\text { by X-ray }\end{array}$ & $\begin{array}{c}\text { Nominal } \\
\text { thickness }\end{array}$ & $\begin{array}{c}\text { Measured by } \\
\text { Metroscope }\end{array}$ \\
\hline Polyester & 4.2 & 4 & $4-6$ \\
$\mathrm{C}_{10} \mathrm{H}_{8} \mathrm{O}_{4}$ & 6.8 & 6 & $7-14$ \\
Density1.39 $\mathrm{g} \mathrm{cm}^{-3}$ & 14.0 & 12 & 14 \\
& 30.0 & 25 & $26-30$ \\
\hline
\end{tabular}

線とレーリー散乱線の両方からなる）である。散乱線の理 論強度計算を FP 法に利用する開発とその実用化は, 1990 年代になってから本格的に始まった。散乱線は, 炭素や酸 素などの軽元素からも発生するので, 散乱線を用いた FP 法は, 樹脂の薄膜測定や, 不定形試料の分析などにも有効 である.また, 炭素, 酸素と水素で構成される有機化合物 の試料について, WDXRF 分析装置を用いたFP法による定 量分析では，炭素と酸素の蛍光 $\mathrm{X}$ 線に加えて Rh K $\alpha$ 線の コンプトン散乱線とレーリー散乱線の強度比から, 炭素, 酸素に加え水素の定量值を求めることもできる ${ }^{18) 19) 20)}$.

以下，散乱線を用いた FP 法の膜厚測定と不定形試料分 析への応用例を紹介する.

$\mathbf{3} \cdot \mathbf{5} \cdot \mathbf{1}$ 樹脂薄膜の膜厚測定 ${ }^{21)}$ 樹脂の主成分である 炭素の蛍光 X 線はエネルギーが低いため, 分析深さは樹脂 の組成にもよるが数 $\mu \mathrm{m}$ 以下である。 一方, ターゲット元 素 $\mathrm{Rh}$ の Rh $\mathrm{K} \alpha$ コンプトン散乱線では, 分析深さは $1 \mathrm{~mm}$ 以上であり, 有機物薄膜の試料では, コンプトン散乱線の ほうが炭素の蛍光X線を用いるより厚い膜厚の測定が可能 である. WDXRF装置を用いて, ポリエステルフィルム（主 成分 $\left.\mathrm{C}_{10} \mathrm{H}_{8} \mathrm{O}_{4}\right)$ を, $\mathrm{Rh} \mathrm{K} \alpha$ コンプトン散乱線のみを測定し て, 薄膜 FP 法でフィルムの厚さを測定した例を Table 7 に 示す. 標準試料には, バルクのポリテトラフルオロエチレ ン（10 mm 厚）を使用した. 参考として接触式万能測長機 による厚さ测定結果も示した。 また, 単独の樹脂薄膜だけ でなく，塗膜のように顔料などの無機成分を含む樹脂薄膜 の膜厚と元素含有量の薄膜 FP 法による同時定量も可能で ある ${ }^{22)}$.

分析試料と異なる成分及び試料形態の異なる樹脂を標準 試料として使用できることも，この方法の利点である.

$3 \cdot 5 \cdot 2$ 散乱線内標準法による不定形試料の定量分析 蛍光 $\mathrm{X}$ 線と散乱 $\mathrm{X}$ 線の強度が試料の形状に応じて同様の変 化をする現象を利用し, 蛍光 X 線と散乱 X 線の強度比を使 用して形状補正を行うことができる. 蛍光 X 線も散乱 X 線 の強度も試料の組成によって変化するので, 散乱 X 線の強 度も理論計算を行い, 次式の測定強度比と理論強度比を用 いた感度曲線式を用いて FP 法定量演算を行う。 


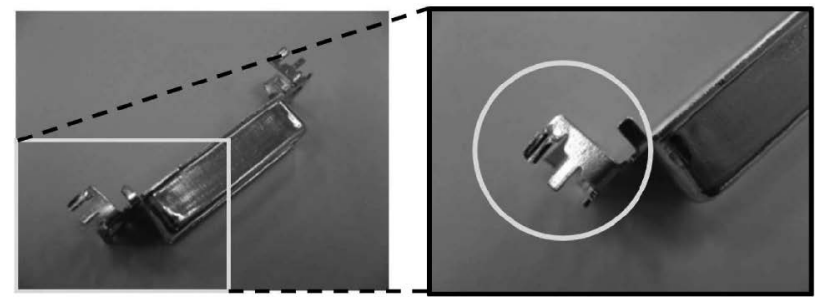

Fig. 10 Measured electric component

$$
\frac{I_{i T f}}{I_{T s}}=b \frac{I_{i M f}}{I_{M s}}
$$

添え字の $T$ は理論強度, $M$ は測定強度であり, $f$ は蛍光 $\mathrm{X}$ 線， $s$ は散乱 X 線である。このように蛍光 X 線と散乱 $\mathrm{X}$ 線との強度比を使用する方法を散乱線内標準法と呼ぶ.

応用例として, 汎用 EDXRF 分析装置による電子部品の $\mathrm{Sn}$ めっき中の $\mathrm{Pb}$ の定量分析を紹介する ${ }^{23)}$. 電子部品中の $\mathrm{Pb}$ は, EU の RoHS 指令における規制元素であり, 最大許 容濃度は $1000 \mathrm{ppm}$ である.

電子部品の $\mathrm{Sn}$ めっき試料は, 鋼板基板上に Sn めっきが 施されているので, 試料モデルは, $\mathrm{Sn}$ と $\mathrm{Pb}$ の 2 元素系の $\mathrm{Sn}$ めっきとし, 基板は $\mathrm{Fe}$ とした. 測定線は, $\mathrm{Pb} \mathrm{L} \beta_{1}, \mathrm{Sn}$ $\mathrm{K} \alpha$ と $\mathrm{Rh} \mathrm{K} \alpha$ 線（X 線管ターゲット $\mathrm{Rh}$ のレーリー散乱線） として, FP 法の定量演算には, $\mathrm{Pb} \mathrm{L} \beta_{1} / \mathrm{Rh} \mathrm{K} \alpha$ と $\mathrm{Sn} \mathrm{K} \alpha$ / $\mathrm{Rh} \mathrm{K} \alpha$ の強度比を使用して, 薄膜 $\mathrm{FP}$ 法でめっき厚さと $\mathrm{Pb}$ 含有率の定量分析を行った。標準試料には, MBH 製の 5 点 の $\mathrm{Pb}$ フリーはんだのディスク標準試料を使用して, 強度 比の感度曲線を作成した. Fig. 10 に分析試料である電子部 品の写真を示す. 写真 Fig. 10（b）の円が直径 $10 \mathrm{~mm}$ の測 定領域である.

Table 8 にめっき厚さと $\mathrm{Sn}$ めっき中 $\mathrm{Pb}$ の定量值を示 す. また, 参考のため, 測定径 $50 \mu \mathrm{m}$ の微小部 EDXRF で, 同一試料の $\mathrm{Sn}$ めっき部の平坦な部分を測定した結果も示 した. 本方法は, 測定径 $10 \mathrm{~mm}$ でめっき部以外も測定領 域となっており，また，測定部が平坦ではないにもかかわ らず，微小部 EDXRFの結果とよく一致した。

\section{4 結 言}

FP 法は, スタンダードレス分析, 薄膜 FP 法を含め蛍光 $\mathrm{X}$ 線析における多大な技術革新をもたらしたと言える.FP 法が開発された当初, 30 数年前の蛍光 X 線分析装置では, コンピュータの処理速度が遅く, 元素数が多い場合には 1 試料の FP 法定量演算に 30 分から 1 時間を要し, 利用が限 定的であったが, 現在では瞬時に結果が得られるように なった.

本稿では, 五つの分野で代表的な応用例の要点のみ紹介 したが, それ以外の多くの改良, 機能追加を行った. FP 法
Table 8 Analyzed result of Sn coating on an electric part using shape correction

\begin{tabular}{lcrc}
\hline \multicolumn{1}{c}{ Method } & $\begin{array}{c}\text { Thickness } \\
\mu \mathrm{m}\end{array}$ & Pb ppm & Sn mass \% \\
\hline Shape correction & 6.0 & 1430 & 99.86 \\
without shape correction & 2.3 & 968 & 99.90 \\
Micro-EDXRF & 5.4 & 1388 & - \\
\hline
\end{tabular}

の応用として，スタンダードレス分析は，スクリーニング 分析を主として広く一般的に利用されるようになってお り，また，理論マトリックス補正係数を使用した検量線法 も JIS など規格分析法として採用が増えてきている ${ }^{24)}$. ま た, 薄膜 FP 法は, 半導体を含む電子材料業界では, 不可 欠の分析手法とされている。ところが，バルク FP 法定量 分析は, 電子材料など産業界での利用は, まだ限定的であ る. 今後の課題としては, より簡単な操作で, 分析試料に 応じた FP 法を利用した最適手法の採用により, さらに精 確な分析が行えるように改良を進めて行きたいと考えてい る.

\section{文献}

1) J. Sherman : Spectrochem. Acta, 7, 283 (1955).

2) T. Shiraiwa, N. Fujino: Jpn. J. Appl. Phys., 5, 886 (1966).

3) J. W. Criss, L. S. Birks : Anal. Chem., 40, 1080 (1968).

4) JIS G 1256, 鉄及び鋼一蛍光X線分析方法 (1973).

5) D. Laguitton, M. Mantler : Adv. X-ray Anal., 20, 515 (1977).

6) J. W. Criss : Adv. X-ray Anal., 23, 93 (1980).

7) 越智寛友, 岡下英男: 島津評論, 45, 51 (1988).

8) 河野久征, 荒木庸一, 片岡由行, 村田 守: X線 分析の進歩, 23, 177 (1989).

9) 河野久征, 村田 守, 片岡由行, 新井智也：X線 分析の進歩, 19, 307 (1988).

10) Y. Kataoka : The RIGAKU JOURNAL, 6, 33 (1989).

11) Y. Kataoka, N. Kawahara, S. Hara, Y. Yamada, T. Matsuo, M. Mantler: Adv. X-ray Anal., 49, 255 (2006).

12) Y. Kataoka, T. Arai : Adv. X-ray Anal., 33, 225 (1990).

13) 越智寛友, 塩田忠弘, 西埜 誠 : 島津評論, 49, 85 (1992).

14) H. Homma, H. Inoue, M. Feeney, L. Oelofse, Y. Kataoka: Adv. X-ray Anal., 55, 242 (2012).

15) Y. Kataoka, H. Homma, H. Kohno: Metallurgical Analysis, 31, 18 (2011).

16) K. Kawakyu, A. Morikawa, K. Watanabe, Y. Yamada, Y. Kataoka : Adv. X-ray Anal., 59, 255 (2016).

17) Y. Kataoka, E. Furusawa, H. Kohno, T. Arai, A. Martin, H. Inoue, M. Mantler : Adv. X-ray Anal., 52, 83 (2007).

18) 西埜 誠, 田中 武, 岡下英男: 第 27 回 $X$ 線分析 討論会講演要旨集, 49 (1990).

19) 西埜 誠, 田中 武, 岡下英男：第 55 回分析化学 討論会講演要旨集, 123 (1991). 
20) 西埜 誠, 田中 武, 岡下英男：第 28 回 X線分析 討論会講演要旨集, 63 (1992).

21) 越智寛友, 塩田忠弘, 西埜 誠：分析化学 (Bunseki Kagaku), 43, 371 (1994).

22) 小川理絵, 越智寛友, 西埜 誠, 市丸直人, 大和亮
介, 渡邊信次：X線分析の進歩, 40, 233 (2009).

23) H. Ochi, S. Watanabe, H. Nakamura : X-Ray Spectrom., 37, 245 (2008).

24) 片岡由行：X線分析の進歩, 50, 33 (2019).

\title{
Development and Applications of a Fundamental Parameter Method for X-ray Fluorescence Analysis
}

\author{
Yoshiyuki KataOKA $^{* 1}$, Hisayuki Kohno ${ }^{1}$, Naoki Kawahara ${ }^{1}$, Hirotomo OCHI ${ }^{2}$, \\ Makoto NISHINO ${ }^{3}$ and Hideki NAKAMURA ${ }^{3}$ \\ * E-mail : kataoka@rigaku.co.jp
}

${ }^{1}$ Rigaku Corporation, 14-8, Akaoji-cho, Takatsuki-shi, Osaka 569-1146

${ }^{2}$ Research center, Shimadzu General Services, 1, Nishinokyo Kuwabara-cho, Nakagyo-ku, Kyoto-shi, Kyoto 6048511

${ }^{3}$ Analytical \& Measuring Instruments Division, Shimadzu Corporation, 1, Nishinokyo Kuwabara-cho, Nakagyo-ku, Kyoto-shi, Kyoto 604-8511

(Received November 28, 2019; Accepted January 20, 2020)

The fundamental parameter (FP) method allows calculation of X-ray intensities theoretically and is used in various aspects of X-ray fluorescence (XRF) quantitative analysis. Wavelength dispersive X-ray fluorescence (WDXRF) spectrometers capable of performing the FP method were first developed in the late 1980s by Japanese manufacturers Rigaku and Shimadzu. Since then, through broadening of features including application to energy dispersive X-ray fluorescence (EDXRF) spectrometers and continuous improvements, it is now commonly used in various fields. The FP method is not only used for standardless analysis allowing quantification without type standards, but also for the analysis of coating and thin film thicknesses. It has also been adopted by JIS and ISO standard test methods of various materials as a method to calculate the matrix correction coefficients applied to the conventional calibration equation. FP method incorporating scattering X-ray intensities has also been developed for the analysis of polymers and biological samples and is also beneficial for the analysis of irregularly shaped samples. The authors recognize that the FP methods developed by the authors and their groups greatly contributed to the expansion of applications of X-ray fluorescence analysis.

Keywords: X-ray fluorescence analysis; fundamental parameter method; Matrix correction, Scattering X-rays, standardless analysis. 